\title{
KOMUNIKASI INTERPERSONAL ORANG TUA DALAM MENDIDIK ANAK MENURUT AL QURAN (Suatu Kajian Tafsir Tematik Komunikasi)
}

\author{
Aidil Haris \\ Dosen Fakultas Komunikasi \\ Universitas Muhammadiyah Riau
}

\begin{abstract}
Abstrak
Jika kita menyimak isi media massa beberapa tahun belakangan, persoalan mendasar yang sering muncul adalah seputar pemberitaan kasus kriminalitas orang tua dan anak. Ada pemberitaan seputar orang tua membunuh anaknya. Ada pula pemberitaan tentang orang tua menelantarkan anaknya. Kemudian pemberitaan seputar anak membunuh orang tuanya. Peristiwa ini tentu menjadi potret buram tentang tindakan orang tua terhadap anak yang dianggap tidak berprikemanusiaan. Peran orangtua dalam keluarga tidak sebatas merawat dan membesarkan anak, tapi lebih daripada itu bagaimana orangtua mampu mendidik anaknya sejak dini hingga anaknya menjadi besar dan terdidik. Yang menjadi hal terpenting bagi orang tua pada hakikatnya adalah bagaimana orang tua mampu membangun komunikasi interpersonal yang efektif dengan anak-anaknya. Apabila komunikasi interpersonal orangtua dan anak ini sudah terbangun secara baik, maka hubungan pertalian darah antara orangtua dan anak tidak akan mudah terpengaruhi oleh lingkungan sekitarnya
\end{abstract}

Kata Kunci : Komunikasi Interpersonal, Orang tua, Anak

\section{A. Pendahuluan}

Jika kita menyimak isi media massa beberapa tahun belakangan, persoalan mendasar yang sering muncul adalah seputar pemberitaan kasus kriminalitas orang tua dan anak. Ada pemberitaan seputar orang tua membunuh anaknya. Ada pula pemberitaan tentang orang tua menelantarkan anaknya. Kemudian pemberitaan seputar anak membunuh orang tuanya. Peristiwa ini tentu menjadi potret buram tentang tindakan orang tua terhadap anak yang dianggap tidak berprikemanusiaan.

Apabila kita berfikir sejenak, maka muncul tanda tanya besar dalam pikiran kita tentang mengapa orang tua tega menelanatarkan anaknya dan bahkan tidak khawatir sampai membunuh anak kandungnya sendiri? Lalu, bagaimana pula dengan anak durhaka yang tega- 
teganya membunuh orangtua kandungnya sendiri. Ada apa dibalik semua peristiwa ini? Siapa yang salah? Apakah orangtua yang salah atau anaknya yang salah? Bila kita menyimak dengan kasat mata maka asumsi yang muncul adalah bahwa persoalan ini merupakan persoalan yang sangat memilukan kehidupan keluarga. Akar masalah dari semua itu salahsatunya adalah persoalan komunikasi orangtua dan akan yang tidak terbangun dengan baik.

Harus diakui, menjadi orangtua yang bijaksana tidak semudah yang dibayangkan. Peran orangtua dalam keluarga tidak sebatas merawat dan membesarkan anak, tapi lebih daripada itu bagaimana orangtua mampu mendidik anaknya sejak dini hingga anaknya menjadi besar dan terdidik. Yang menjadi hal terpenting bagi orang tua pada hakikatnya adalah bagaimana orang tua mampu membangun komunikasi interpersonal yang efektif dengan anak-anaknya. Apabila komunikasi interpersonal orangtua dan anak ini sudah terbangun secara baik, maka hubungan pertalian darah antara orangtua dan anak tidak akan mudah terpengaruhi oleh lingkungan sekitarnya.

Atas dasar itulah,penulis menala'ah lebih rinci tentang bagaimana komunikasi interpersonal orangtua dan anak menurut Alquran sehingga para orangtua dapat mendidik anak sesuai tuntutan Islam. Pada paparan pembahasan ini, penulis mengutip Alquran surah Ash-Shaaffat ayat 100-107 tentang komunikasi interpersonal yang dibangun oleh Nabi Ibrahim, AS ketika mendidik anaknya Nabi Ismail, AS. Dalam sejarah Islam disebutkan bahwa Nabi Ibrahim, AS merupakan seorang nabi, pendidik, ayah dan suami yang sukses mendidik keluarga dan ummat. Kualitas keimanan, keshalehan dan kepemimpinannya sebagai seorang Nabi utusan Allah tak perlu diragukan lagi. Begitu halnya dengan perannya sebagai seorang ayah dan pendidik di tengah-tengah keluarganya. Meskipun demikian tentu tidak mudah bagi kita untuk memahami atau menela'ah konsep-konsep pendidikannya dalam mendidik keluarga dan ummat.

Model dan konsep komunikasi interpersonal Nabi Ibrahim dalam mendidik anaknya Ismail, AS inilah yang akan penulis kaji untuk dijadikan panduan bagi orangtua dalam mendidik anak-anaknya. 


\section{B. Komunikasi Interpersonal Orang Tua Dalam Mendidik Anak Menurut Al Quran}

\section{Alquran Surah Ash-Shaaffat Ayat 100-102}

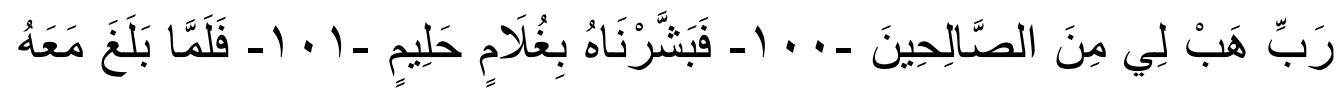

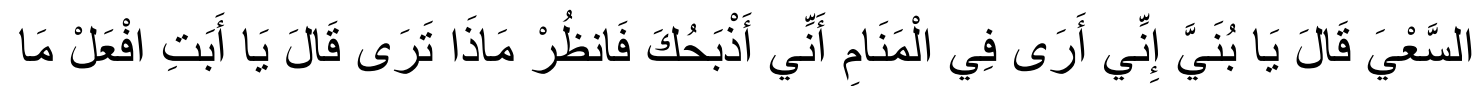

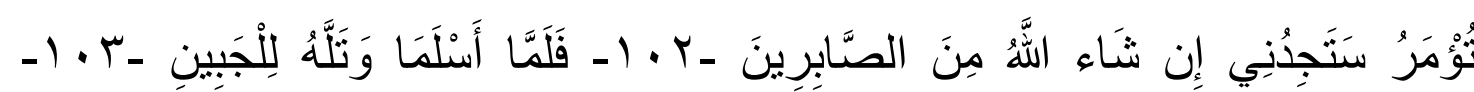

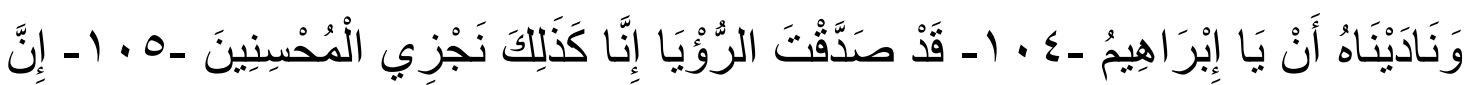

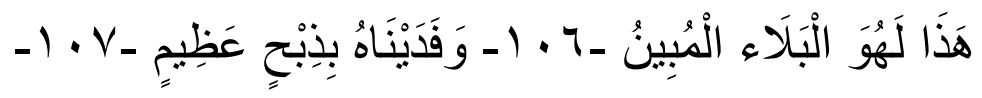

\section{Artinya:}

"Ya Tuhanku, anugerahkanlah kepadaku (seorang anak) yang termasuk orangorang yang saleh.(!00) Maka Kami beri Dia khabar gembira dengan seorang anak yang amat sabar.(101) Maka tatkala anak itu sampai (pada umur sanggup) berusaha bersamasama Ibrahim, Ibrahim berkata: "Hai anakku Sesungguhnya aku melihat dalam mimpi bahwa aku menyembelihmu. Maka fikirkanlah apa pendapatmu!" ia menjawab: "Hai bapakku, kerjakanlah apa yang diperintahkan kepadamu, insya Allah kamu akan mendapatiku termasuk orang-orang yang sabar".(102) Tatkala keduanya telah berserah diri dan Ibrahim membaringkan anaknya atas pelipis(nya), (nyatalah kesabaran keduanya ).(103) Dan Kami panggillah dia: "Hai Ibrahim,(104) Sesungguhnya kamu telah membenarkan mimpi itu, Sesungguhnya demikianlah Kami memberi Balasan kepada orangorang yang berbuat baik. .(105) Sesungguhnya ini benar-benar suatu ujian yang nyata.(106) dan Kami tebus anak itu dengan seekor sembelihan yang besar.(107). (Al-Quran \& Terjemahan, 1990)

a. Penafsiran Surah Ash-Shaaffat Ayat 100-107

Untuk memberikan penafsiran terhadap surat Ash-Shaaffat ayat 100-107, penulis mengutip penafsiran dari ulama tafsir Quraish Shihab dalam tafsir Al Mishbah. Berikut disajikan penafsiran surat Ash-Shaaffat ayat 100-107.

b. Tafsir Surah Ash-Shaaffat Ayat 100-101

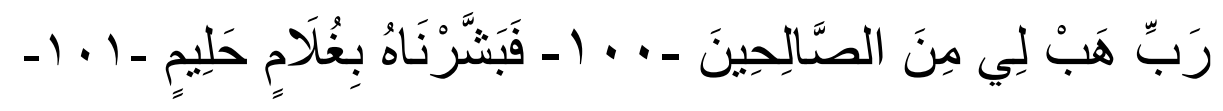

Ayat 100: Ya Tuhanku, anugrahkanlah kepadaku (seorang anak) yang termasuk orang-orang yang saleh. Amat sabar.

Ayat 101. Maka Kami beri Dia khabar gembira dengan seorang anak yang 
Di dalam tafsir Al-Mishbah dijelaskan bahwa:

"Nabi Ibrahim ketika itu berada di Ur, negeri Kaldania memutuskan untuk berhijrah agar dapat menjalankan misinya dengan baik.Dan ia berkata kepada beberapa orang kepercayaan bahkan mengumumkan tekadnya di hadapan masyarakat umum bahwa:"Sesungguhnya aku akan pergi mеnијu kesatu tempat di mana aku dapat leluasa mengabdi kepada Tuhanku tanpa diganggu oleh siapapun, dan Dia akan menunjukiku jalan yang terbaik”. Karena ketika itu beliau tidak menemukan seorangpun yang dapat menggantikannya sebagai penerus, maka beliau berdoa tanpa menggunakan panggilan "Ya/wahai" untuk mengisyaratkan kedekatan beliau kepada Allah:"Tuhanku, anugerahkanlah kepadaku seorang anakyang termasuk kelompok orang-orang yang shaleh.Maka Kami memberinya kabar gembira bahwa dia akan dianugerahi dengan seorang anak yang amat penyantun.

Kata ghulam adalah seorang pemuda yang telah tumbuh memanjang kumisnya. Biasanya yang mencapai usia tersebut telah tumbuh pesat pula nafsu seksualnya, karena itu nafsu seksual dinamai juga ghulmah.

Kata halim, mempunyai tiga makna dasar, yaitu tidak tergesa-gesa, lubang karena kerusakan serta mimpi. Bagi manusia, tidak tergesa-gesa lahir dari ketidaktahuan seseorang atau keraguannya, ketika itu ia tidak dapat dinamai halim, walaupun ia tidak tergesa.

Dengan demikian dapat dipahami bahwa kabar gembira yang disampaikan itu mengandung isyarat bahwa anak tersebut adalah seorang anak lelaki, dari kata ghulam. Ia sudah mencapai usia dewasa, dipahami dari sifatnya sebagai seorang yang halim/penyantun,karena seorang yang belum dewasa, tidak dapat menyandang sifat tersebut."(Tafsir Al Mishbah)

c. Tafsir Surah Ash-Shaaffat Ayat 102

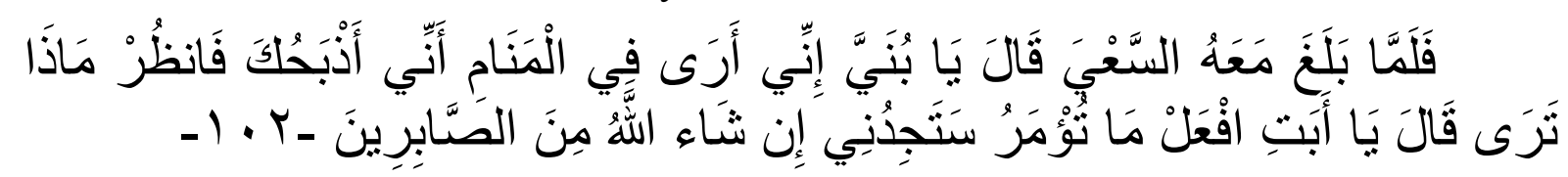

"Maka tatkala anak itu sampai (pada umur sanggup) berusaha bersama-sama Ibrahim, Ibrahim berkata: "Hai anakku Sesungguhnya aku melihat dalam mimpi bahwa aku menyembelihmu. Maka fikirkanlah apa pendapatmu!" ia menjawab: "Hai bapakku, kerjakanlah apa yang diperintahkan kepadamu, insya Allah kamu akan mendapatiku termasuk orang-orang yang sabar".

Allah telah menepati janjiNya kepada Nabi Ibrahim tentang perolehan anak. Demikian hingga anak tersebut lahir dan tumbuh menjadi remaja. Maka tatkala ia telah mencapai usia yang menjadikan ia mampu berusaha bersamanya, maka Ibrahim berkata: "Hai 
anakku Sesungguhnya aku melihat dalam mimpi bahwa aku menyembelihmu, dan engkau tentu tahu bahwa mimpi para nabi adalah wahyu ilahi. Maka fikirkanlah apa pendapatmu, sang anak menjawab dengan penuh hormat: "Hai bapakku, kerjakanlah apa yang diperintahkan kepadamu, insya Allah kamu akan mendapatiku termasuk orang-orang yang sabar.

Sabagaimana dijelaskan dalam tafsir Al Mishbah bahwa:

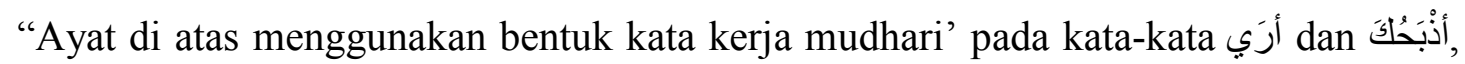
Begitu juga pada kata تُؤَْْرَ Ini mengisyaratkan apa yang beliau lihat itu seakan-akan masih terlihat hingga saat penyampaiannya itu. Sedangkan kata penyembelihan untuk mengisyaratkan bahwa perintah Allah yang dikandung mimpi tersebut belum selesai dilaksanakan. Karena itu pula jawaban anak menggunakan kata kerja masa kini juga untuk mengisyaratkan bahwa ia siap.

Ucapan anak:"Engkau akan mendapatiku insya Allah termasuk para penyabar, dengan mengaitkan kesabarannya dengan kehendak Allah, menunjukkan betapa tinggi akhlak dan sopan santun kepada Allah dan orangtuanya". (Tafsir Al Mishbah:62:63)

d. Tafsir Surah Ash-Shaaffat Ayat 103-107

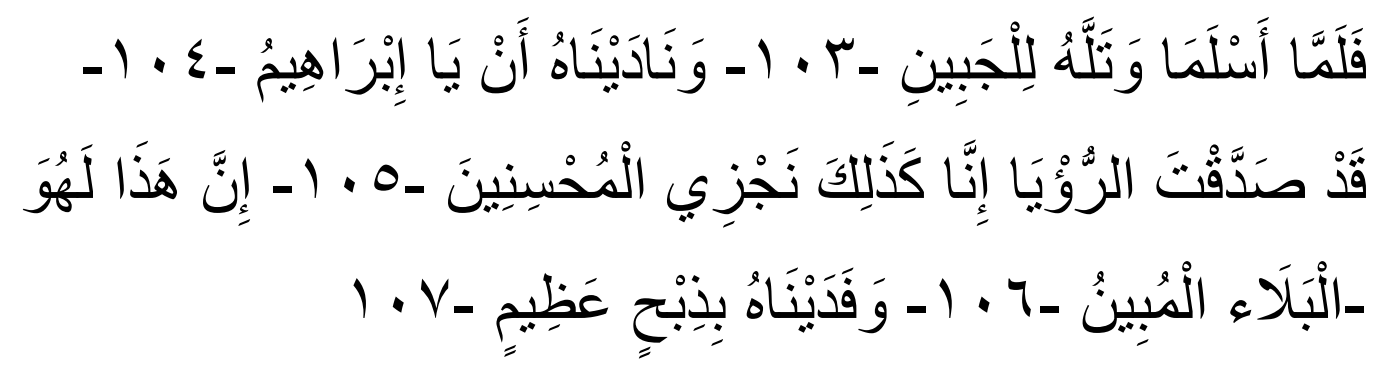

"Maka tatkala keduanya telah berserah diri dan Ibrahim membaringkan anaknya atas pelipis(nya), (nyatalah kesabaran keduanya ).104. dan Kami panggillah dia: "Hai Ibrahim,Sesungguhnya kamu telah membenarkan mimpi itu Sesungguhnya demikianlah Kami memberi balasan kepada orang-orang yang berbuat baik.106. Sesungguhnya ini benar-benar suatu ujian yang nyata.107. dan Kami tebus anak itu dengan seekor sembelihan yang besar".

Quraish Shihab dalam tafsir Al Misbah menafsirkan bahwa:

"Ayat yang lalu menguraikan kesediaan anak untuk disembelih atas perintah Allah. Maka tanpa ragu tatkala keduanya telah berserah diri secara penuh dan tulus kepada Allah dan Ibrahim membaringkan anaknya atas pelipisnya, maka ketika itu terbukti kesabaran keduanya. Pisau yang begitu tajam atas kuasa Kami tidak melukai Ismail sedikitpun dan Kamimelalui Malaikat memanggilnya:"Hai Ibrahim, sungguh engkau telah membenarkan mimpi, karena itu Kami memberimu ganjaran dengan menjadikanmu imam dan teladan bagi 
orang-orang bertakwa. Sesungguhnya perintah menyembelih anak serta kewajiban memenuhinya benar-benar suatu ujian yang nyata yang tidak dapat dipikul kecuali manusia pilihan.

Kata ( ت ) yaitu tempat yang tinggi. Ada juga yang memahami tumpukan pasir/ tanah yang keras. Maksud ayat ini adalah membaringkan dan meletakkan pelipisnya pada tempat

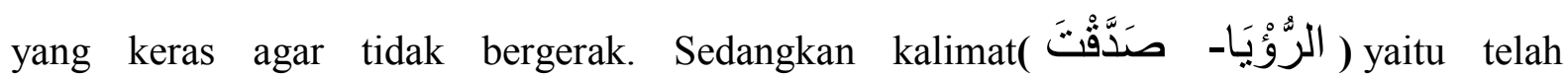
membenarkan mimpi itu, dan melaksanakan sesuai dengan kemampuan yang diperintahkan Allah melalui mimpi. Boleh jadi Nabi Ibrahim hanya bermimpi menyembelih anaknya, tanpa melihat adanya darah yang memancar, apalagi yang menyebabkan kematian ataupun mungkin juga melihat dalam mimpinya Ismail berlumuran darah dan itulah yang beliau lakukan tetapi perintah yang dimimpikan itu dibatalkan Allah. Demikian Nabi Ibrahim telah melaksanakan perintah, seandainya tidak ada panggilan untuk itu, tentu ia akan terus berupaya sehingga terpenuhi perintahNya.

Firman-Nya: (إِنَّ هَذَا لَهُوَ الْبَلَاء الْمُبِينُ), yaitu Sesungguhnya ini benar-benar suatu ujian yang nyata. Ujian yang dimaksud disini merupakan cobaan terhadap Nabi Ibrahim dengan mengorbankan anak satu-satunya yang sangat disayangi dan berpuluh tahun lamanya menanti kehadirannya, oleh Allah justru diperintahkan untuk disembelih oleh ayahnya sendiri Ayat berikutnya:

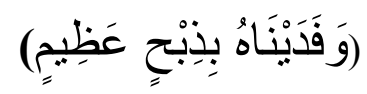

Yaitu Dan Kami menembusnya dengan seekor sembelihan yang besar, yaitu seekor kibas yang besar dan sempurna.

Dengan demikian Penafsiran ayat di atas, memuat penjelasan tentang permohonan Nabi Ibrahim untuk memperoleh anak, doa terkabul dengan anak yang amat penyabar, mimpi Nabi Ibrahim menyembelih Ismail, Nabi Ibrahim mendialogkan mimpinya kepada Ismail, pelaksanaan penyembelihan dan diakhiri dengan keselamatan Ismail, yang berarti kesuksesan misi Nabi Ibrahim, sebagai Rasul yang benar-benar pilihan.(Tafsir Al Mishbah:66)

\section{Memahami Komunikasi Interpersonal}

Jika kita pahami sejenak bahwa pergaulan manusia sehari-hari merupakan bagian dari bentuk peristiwa komunikasi. Sadar atau tanpa disadari, setiap saat kita selalu melakukan proses komunikasi. Menurut Scrhamm diantara manusia yang bergaul, ada yang saling membagi informasi, namun ada pula yang membagi gagasan dan sikap.(Syaiful Rohim, 2009:69) 
Begitu pula menurut Merril dan Lownstein (dalam Syaiful Rohim, 2009:69) bahwa dalam lingkungan pergalana antarmanusia selalu terjadi penyesuain pikiran, penciptaan symbol yang mengandung pengertian bersama. Theodorson selanjutnya mengemukakan pula bahwa komunikasi adalah proses pengalihan informasi dari satu orang atau sekelompok orang dengan menggunakan symbol-simbol tertentu kepada satu orang atau sekelompok lain.

Menurut Rohim, pengalihan informasi tersebut selalu mengandung pengaruh tertentu. Komunikasi yang efektif ditandai dengan hubungan interpersonal yang baik. (Syaiful Rohim, 2009:69-70)

Little John (dalam Rulli Nasrullah, 2012) menjelaskan bahwa komunikasi interpersonal atau komunikasi antarpribadi merupakan proses komunikasi yang terjadi diantara satu individu dengan individu lainnya. Komunikasi di level ini menempatkan interaksi tatap muka diantara dua individu tersebut dalam kondisi yang khusus (private setting).

Steward L. Tubbs dan Sylvia Moss (dalam Deddy Mulyana, 2005) mengatakan ciriciri komunikasi antarpribadi adalah peserta komunikasi berada dalam jarak yang dekat, peserta komunikasi mengirim dan menerima pesan secara simultan dan spontan, baik secara verbal maupun non verbal.

\section{Komunikasi Interpersonal Orangtua dan Anak Menurut Alquran}

Komunikasi interpersonal yang dilakukan Nabi Ibrahim AS dengan anaknya Ismali merupakan bagian dari model komunikasi diadik. Dalam buku Teori Komunikasi (Syaiful Rohim, 2009:70) bahwa komunikasi diadik merupakan proses komunikasi interpersonal yang berlangsung antar dua orang. Orang pertama adalah komunikator yang menyampaikan pesan dan seorang lagi adalah komunikan yang menerima pesan. Dalam komunikasi ini komunikator selalu memusatkan perhatiannya hanya kepada diri komunikan seorang tersebut, sehingga ketika dialog terjadi diantara keduanya selalu berlangsung serius dan intensif.

Dari kisah Nabi Ibrahim AS beserta penafsirannya diatas dapat dipahami bahwa komunikasi interpersonal antara Nabi Ibrahim dan anaknya Ismail menunjukkan betapa bersahabatnya seorang ayah dan anak ketika bertutur kata, meskipun harus mengutarakan sesuatu yang pahit di hadapan anaknya. Dalam hal ini tergambar aktualisasi komunikasi interpersonal Nabi Ibrahim dalam mendidik anaknya Ismail dalam Surah As-Shaffat 100-107, yang dimulai dengan penyerahan diri secara totalitas kepada Allah sebagai bukti penghambaannya yang diiringi dengan doa. Hal ini menunjukkan bahwa Ibrahim sebagai 
orangtua sangat bijaksana mengajarkan nilai-nilai ketuhanan kepada anaknya sebagai landasan hidup.

Ketika Nabi Ibrahim telah dianugerahi anak oleh Allah SWT, lalu Ibrahim AS diperintahkan Allah SWT untuk menyembelih anaknya, Ismail. Jika kita simak kisah tersebut lalu kita bawakan kepada diri kita sebagai seorang anak atau sebagai orang tua, maka tentu banyak pertentangan yang muncul dari dalam diri kita sendiri. Akan tetapi berbeda halnya dengan Ibrahim AS yang sabar menerima perintah tersebut yang tidak hanya melibatkan pengendalian emosional, tetapi juga kematangan spiritual (iman) yang tinggi. Disini jelas terlihat bahwa kepatuhan dan ketaatan Nabi Ibrahim tanpa membantah langsung melaksanakan perintah dari Allah SWT.

Menariknya lagi, Ismail sebagai seorang anak justru tidak membantah apa yang menjadi permintaan orangtuanya, Nabi Ibrahim, AS. Ismail dengan sikap menjunjung tinggi nilai-nilai sopan santun menyerahkan diri sebagai bentuk kepatuhan dan ketaatannya kepada orang tua untuk disembelih. Seolah-olah keduanya tidak ada beban sedikitpun dalam menjalankan perintah Allah.

Dari kisah Nabi Ibrahim tersebut diatas, jika kita tela'ah lebih dalam maka dapat ditarik pemahaman bahwa konsep komunikasi interpersonal orang tua dalam mendidik anaknya sebagaimana dikisahkan dalam Alquran surah Ash-Shaaffat ayat 100-107 yaitu:

\section{Pentingnya Menanamkan Konsep Diri}

Do'a Nabi Ibrahim, AS kepada Allah SWT untuk dianugerahi seorang anak yang saleh merupakan sebuah pengharapan yang dinanti-nantikan Ibrahim, AS. Meski akhirnya Allah SWT mengabulkan permohonan Ibrahim AS. Penantian panjang Ibrahim mengharapkan anak merupakan sebuah upaya menanamkan konsep diri. Alhasil, nilai-nilai kesabaran merupakan hal terpenting yang harus dimiliki oleh seseorang. Konsep diri merupakan pandangan dan perasaan kita tentang diri kita sendiri. Nabi Ibrahim menyadari bahwa ia adalah seorang manusia yang lemah. Yang kuasa hanyalah Allah SWT. Penanaman nilai aqidah inilah yang dimiliki oleh Ibrahim dan kemudian ditanamkan pada anaknya Ismail. Ketika orang tua telah mengenal akan dirinya yang sesungguhnya maka setiap berperilaku dan bertingkah laku ia akan selalu 'berkaca' terlebih dahulu dan memahami bahwa dalam setiap kehidupan ini hanya Allah SWT yang menjadi penguasa. Penanaman konsep diri yang sesungguhnya dapat dilihat bagaimana orangtua menanamkan aqidah kepada anaknya. 
2. Sikap Terbuka dan Suportivinies

Pada Alquran surah Ash-Shaaffat ayat 102 yang artinya:

"Maka tatkala anak itu sampai (pada umur sanggup) berusaha bersama-sama Ibrahim, Ibrahim berkata: "Hai anakku Sesungguhnya aku melihat dalam mimpi bahwa aku menyembelihmu. Maka fikirkanlah apa pendapatmu!" ia menjawab: "Hai bapakku, kerjakanlah apa yang diperintahkan kepadamu, insya Allah kamu akan mendapatiku termasuk orang-orang yang sabar."

Dari terjemahan diatas sebagaimana juga sudah dijelaskan dalam tafsir al Mishbah, bahwa pernyataan Nabi Ibrahim yang mengungkapkan tentang mimpinya untuk menyembelih Ismail merupakan bagian dari sikap keterbukaannya kepada Ismail. Hal ini menunjukkan bahwa orangtua harus mampu menciptakan suasana terbuka dalam proses komunikasi interpersonal pada saat mendidik anak. Yang lebih menariknya lagi, Ismail sebagai seorang anak juga memberikan dukungan (suportivinies) yang luar biasa terhadap keterbukaan yang diberikan oleh ayahnya, Ibrahim. Hal ini terbukti dari direkamnya pernyataan Ismail dalam Alquran yang artinya: “......Hai bapakku, kerjakanlah apa yang diperintahkan kepadamu, insya Allah kamu akan mendapatiku termasuk orang-orang yang sabar.

\section{Sikap Perasaan Positif}

Salah satu ciri komunikasi interpersonal menurut De Vito adalah adanya perasaan positif diantara komunikator dan komunikan. Dari kisah Ibrahim dapat kita ambil pelajaran bahwa jika orang tua selalu berprasangka positif kepada orang lain, maka akan muncul perasaan positif dalam diri kita sendiri. Hal ini menjadi bagian dari terciptanya suasana interpersonal yang efektif. Ketika Ibrahim mengutarakan kisah mimpinya kepada Ismail, maka umpan balik yang diberikan Ismail adalah jawaban positif yang dilahirkan dari perasaan positif. 


\section{E. Kesimpulan}

Apa yang disebutkan oleh banyak para ahli komunikasi tentang pola komunikasi interpersonal yang efektif bagi orangtua dalam mendidik anak di tengah-tengah keluarga, ternyata telah dijawab oleh Allah SWT dalam Alquran dengan menceritakan banyak kisah. Salah satunya adalah kisah Nabi Ibrahim AS yang diperintahkan oleh Allah SWT untuk menyembelih anaknya tatka ia sedang menikmati indahnya kehadiran seorang anak di tengah-tengah keluarga. Lalu dialog antara Ibrahim dan anaknya tersebut diabadikan dalam Alquran sebagai pelajaran berharga bagi orangtua dalam membangun komunikasi interpersonal dengan anaknya. Jadi, bila kita tarik kesimpulan dari pembahasan materi ini, maka dapat diambil intisarinya bahwa komunikasi interpersonal orangtua dalam mendidik anak dapat dimulai dengan penanaman konsep diri pada diri orangtua itu sendiri dan anak. Kemudian, juga perlu adanya sikap saling terbuka dan menumbuhkan rasa saling mendukung antara orangtua dan anak. Lalu, tanamkan perasaan positif dalam diri orang tua, sehingga anak juga akan turut menanamkan perasaan positif dalam dirinya. 


\section{DAFTAR PUSTAKA}

Departemen Agama Republik Indonesia. Al-Quran \& Terjemahan. Semarang: Toha Putra. 1990.

Mulyana, Deddy, Pengantar Ilmu Komunikasi. Bandung: Remaja Rosda Karya, 2005.

Nasrullah, Rulli. Komunikasi Antar Budaya di Era Budaya Siber. Jakarta: Kencana, 2012.

Rohim, Syaiful. Teori Komunikasi (Perspektif, Ragam \& Aplikasi). Jakarta. Rineka Cipta, 2009.

Shihab, Quraish, Tafsir Al-Mishbah. Cet. IV, Jakarta: Lentera Hati. 2006. 